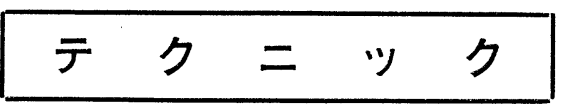

\title{
土㥽から疫病菌を捕え分離する方法
}

桂

筆者" はさきに疫病菌 Phytophthora の分離法につい て述へ，とくに細菌類や Phytophthora 以外の系状菌 との混合から，疫病菌を純粋分離する工夫について記 した．事実, 疫病菌を分離する場合に，いわゆる雑菌 類が混入することは，しばしば分離を困難にしている。 次に述べる方法は，雑菌との混合の甚だしい材料に ついても適用できるが，土壌中の疫病菌を植物体とく に果害で捕え, その発病部分組織から疫病菌を分離し ようとするものである.

被害植物付近の土壤から, また被害植物が腐敗しさ った土壌中から，さらに被害原因が不明であるけれど も疫病を予期する土壌などから, 疫病菌を直接捕えて 分離しようとするものである.

土壤から直接疫病菌を捕え分離する方法はZENTMYER

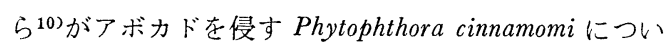
て行なった実験があるが，筆者はこの方法にすこし工 夫を加えた。この方法は, 発生予察に利用できると思 うし，また土境中の疫病菌の評価に関する $\mathrm{TSAO}_{\mathrm{SA}}$ 7の 方法を応用するためにも役立つであろう．

\section{I 果実による土壤中の疫病菌の捕え方}

次に述べる疫病菌の捕え方の根本的な考え方は, も し疫病菌 Phytophthora (Pythium を含む) の菌系ない し遊走子のうが土㭛中に存在するならば, たとえ被害 植物が見られない場合でも, 菌系では直接接触するこ とによって果実の感染を期待し, また土壤中で遊走子 のうを形成するならば，その発芽遊走子が果実に感染 することを期待し，それぞれの感染果実の発病組織部 分から菌を分離しようとするものである。順序に従っ て分離法を次に述へよう。

i）土壤を 1 畨場の 2,3 力所から採取する.

土壤採取は, 被害株周辺のもので根が混入する方が 分離の能率が高い. 直射光の当る場所は表土を $1 \sim 2$ $\mathrm{cm}$ 除く方がよいであろう。

ii）採取土壤を深底シャーレに 20〜30g を入れた
琦 一*

ものをいくつか用意し，それに水道水を土壤面上 0.5〜 $1 \mathrm{~cm}$ の上まで注ぎ入れ，その中に果実を静 置する(第 $1 ， 2 ， 3$ 図).

用うる果実は, 被害植物と同じ種類か近縁のものが 望ましいし，また未熟なものの方がよい，果実がない 場合には第 3 図のように茎葉の若いもの, あるいは実 生幼植物を用いてもよい.

iii）それぞれの装置は期待し得る疫病菌の発育適温 あるいは適温より少し低い場所に置く。

期待すべき疫病菌が種類不明の場合は， $20^{\circ} \mathrm{C}$ と 28

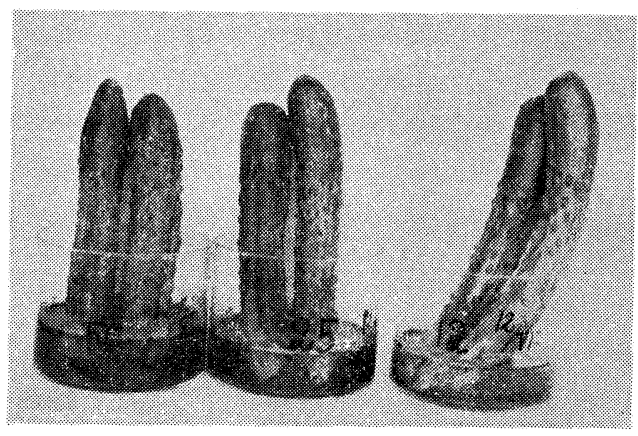

第1図土壇から Phhtophthora melonis 捕える装置

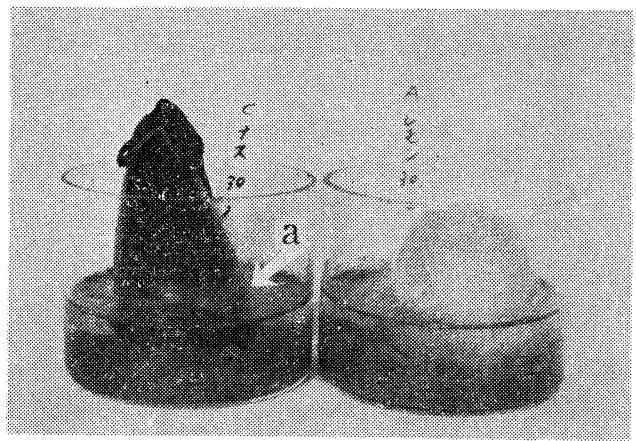

第 2 図土壤から Phytophthora nicotianae var. parasitica を捕える装置

a……斿走子の侵入による水面付近の形成病斑

* 京都府立大学農学部 


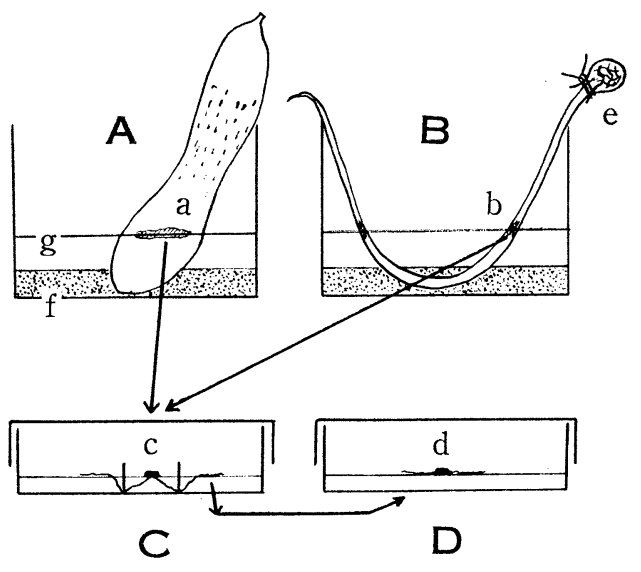

第 3 図土壤から疫病菌を捕え分離する方法

A キュウリ果実で捕える， B 葉で捕える
a, b...形成病斑
f...供試土壤
g...水
e...葉が枯れないよ
うに含水綿を当て ビニールで包む

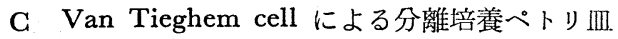
c...a b b 病斑組織の 1 片を cell 内に移植する

D 一般平面培地

d...C の cell 外に伸びて出た菌糸を移植する

${ }^{\circ} \mathrm{G}$ の 2 カ所に分けて置くのがよい.

iv）果実の水面に接する部分に，2〜5日ぐらいの 間に病変が現われるから, その部分組織片から早 目に常法による培地上の分離法を行なう.

水面付近の果実の病変は, 遊走子の走気性Aerotaxis による侵入と思われるが, 果実底部の土壤との接触面 から菌系による侵入もあるから, 果実底部の病変にも 注意を要する. 後者の場合には発病が $1 〜 2$ 日遅れる.

v）病変部組織からの分離は常法による.しかし,

雑菌の混入が予想されるから, 第 3 図に示すよう

にVan Tieghem cell を用いた培地により分離 した方がよい.

もし Phytophthora 以外の禾状菌の混入が予期され るなら, 桂・酒井 ${ }^{5)} に よ り$ 遊走子の砂層通過を得て捕 えるのも便利である.

以上の方法で, 筆者はキュウリ疫病発生地土壤から キュウリ果実をもって容易に Phytophthora molonis 捕え, また神奈川, 愛知, 三重, 大分, 宮崎の各県下 ミカン園ないし苗固土壤から，レモンおよびナスの果 実をもって P. nicotianae var. parasitica ${ }^{9)}$ を捕え, さ らに福井県と京都府のラッキョウ栽培地土裹から, 二 ラの葉をもって P. porri を捕え, それぞれ分離し堷 埕菌株を得た。

\section{II 抗生物質の利用による土壤中の 疫病菌の捕え方}

ここに揭げる抗生物質は，現在わが国で入手しにく いけれど，近い将来入手が容易になるであろう。筆者 は当研究室で昭和 41 年10月 1 月から 10 力月間滞在研究 したカリフォルニヤ大学副教授の Dr. P. H. TsAO の 便宜を得て，それらの抗生物質による直接土壤中から 疫病菌のみを分離する方法を習ったので，文献と合せ てここに御紹介したい.

この方法の骨子は,抗生物質が Phytophthora(Pythium を含む）の発育を抑制しないのに，てれ以外の系状菌 と細菌類の発育を特異的に抑制する性質を有すること を利用するものである。

i） OCANA および $\mathrm{TsAO}^{6)}$ は, PVP 培地法として 次の処方の Difco コーンミール寒天培地により, 多 くの Phytophthora の分離に成功している.

$\begin{array}{ll}\text { Pimaricin } & 10 \mathrm{ppm} \\ \text { Vancomycin } & 200 \mathrm{ppm} \\ \text { PGNB } & 100 \mathrm{ppm}\end{array}$

この処方の寒天培地上に, 被害地土壤内の根の断片 をそのま、置くことによって，ほぼPhtophthoraのみ が発育することによって分離している．被害地土壌の 小量を，同培地上にばらまいても得られるが，この場 合には土壤粒中に疫病菌々系片の混入部が少ないであ ろうから，培地をかなり沢山用意して機会を得なけれ ばならないから，根の断片を捜す方が都合がよい。

次に揭げる 3 つの方法は, OCANA および $\mathrm{TSAO}^{6}$ の 培地に至るまでの発展過程のものであるが，充分でな くとも利用しうる面があるようだから紹介しておく.

ii) ECKERT ら ${ }^{1,2)}$ は早くから pimaricin が Phytophthora の発育を抑制しないで，他の諸菌類の発育を 抑制することに注目し，その10〜 $100 \mathrm{ppm}$ を利用する ことを報告した。

iii) ECKERT ら ${ }^{3)}$ は, 3P 培地法(Three P medium) として次の処方によって P. citrophthora, P. parasitica, および P. cryptogea をミカンとアルファルファの根 から分離した。

pimaricin $100 \mathrm{ppm}$, penicillin 50ppm, polymyxin $50 \mathrm{ppm}$, Difco コーンミール寒天

iv) TsAO および Menyonga ${ }^{8)}$ は, 次の処方の PV 培地法 (PV medium) によって, P. cinnamomi, $P$. citrophthora, P. cryptogea, P. hibernalis, P. palmivora, $P$. parasitica, 扩よび $P$. syringae の分離を得ている. pimaricin $100 \mathrm{ppm}$ vancomycin 200ppm, Difco コーンミール寒天 以上の抗生物質による培地のうち, PVP 培地法が 最もよい結果を得られるようである. 


\section{引用 文 献}

1) Eckert, J. W. and P. H. TsaO (1960): Plant Disease Rept., 44, 660 661.

2) Eckert, J. W., P.H. Tsao, L. J. Klotz and K. B. Jones (1961): Phytopath., 51, 64 65.

3) Eckert, J.W., P.H. TSAO, L. J. KLotz and K. B. Jones(1962): Ibid. 52, 771 777 .

4) 桂 琦一(1964): 土壤病害の手引, II（植物防疫 協会編) $20 \sim 24$.

5）桂 琦一 酒井泰文(1966): 関西病虫研報, 9,
$102 \sim 103$

6) Ocana, G. and P.H.Tsao (1966): Phytopath. $56,893$.

7) TsAo, P.H. (1960): Ibid. 50, 717 724.

8) TsaO, P.H. and J.M. Menyonga (1966): Ibid. $56,152$.

9) Waterhouse, G.M. (1963): Mycol. Papers 92, $1 \sim 22$.

10) Zentmyer, G.A., J. V. Gilpatrick, and W.A. Thron (1960): Phytopath., 50, 87. 